JIOM Nepal, Volume 41, Number 2, August 2019, page 56-58

\title{
Serum Vitamin D Level in Chronic Obstructive Pulmonary Disease and its Relation with Severity: A Single Centre Study
}

\author{
${ }^{1}$ Pankaj Pant, ${ }^{2}$ Shovit Thapa, ${ }^{1}$ Santa K Das, ${ }^{1}$ Niraj Bam \\ 1Deparment of Pulmonology and Critical Care, Mahrajgunj Medical Campus, Tribhuvan University Teaching Hospital, \\ ${ }^{2}$ Manmohan Cardiothoracic Vascular and Transplant Centre, Institute of Medicine, Maharajgunj, Kathmandu, Nepal

\section{Corresponding author:} \\ Pankaj Pant, MBBS, MD \\ Deparment of Pulmonology and Critical Care, Mahrajgunj Medical Campus, Tribhuvan University Teaching Hospital, \\ Maharajgunj, Kathmandu, Nepal \\ Email:drpant2015@gmail.com
}

Submitted: Jun 3, 2019

Accepted : Jul 24, 2019

\begin{abstract}
\section{Introduction}

Chronic obstructive pulmonary disease (COPD) is a public health problem of epidemic proportion. Several studies have shown low serum vitamin $D$ levels in patients with COPD. The aim of this study was to compare serum vitamin D level in patients with Global Initiative for Chronic Obstructive Lung Diseases (GOLD) COPD stage II, III and IV with controls and correlate serum vitamin D level with severity of COPD.
\end{abstract}

\section{Methods}

A cross sectional study was conducted from June 2014 to November 2015 at Tribhuvan University Teaching Hospital (TUTH). A total of 154 subjects were enrolled for study that consisted of 77 cases of COPD and 77 controls for comparison. Participants were taken from medical wards and outpatient department. COPD staging was done as per GOLD guidelines and stage II, III and IV were labeled as advanced COPD cases. Both descriptive and inferential statistics were performed in SPSS version 20.

\section{Results}

Stage II, III and IV COPD were $30 \%, 36 \%$ and $34 \%$ respectively. Mean serum vitamin D level was $15.16 \pm 7.19 \mathrm{ng} / \mathrm{ml}$ in COPD cases and $33.99 \pm 12.37 \mathrm{ng} / \mathrm{ml}$ in healthy controls showing statistically significant relation of low serum vitamin D in patients with advanced COPD $(p<0.0001)$. Serum vitamin D was found to be in decreasing trend with increasing severity of COPD.

\section{Conclusion}

Patients with advanced COPD (GOLD stage II, III and IV) had low serum vitamin D levels compared to normal population and serum vitamin D level correlated with GOLD severity in Nepalese patients with COPD.

Keywords: Chronic obstructive pulmonary disease; global initiative for chronic obstructive lung diseases; vitamin D

\section{INTRODUCTION}

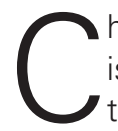

hronic obstructive pulmonary disease (COPD) is one of the commonest preventable and treatable respiratory diseases in clinical practice. It has great implications on global health accounting for significant morbidity and mortality. ${ }^{1}$ It is the fourth leading cause of death worldwide exceeded only by myocardial infarction, malignancy and cerebrovascular disease. COPD is the only one of the 10 leading causes of death for which the mortality rates are still rising. ${ }^{2}$ Vitamin $D$ apart from being a micronutrient, has been shown to have pleiotropic effects including its anti-inflammatory, anti-proliferative, pro-differentiative \& immunological properties. ${ }^{3,4}$ Due to its diverse actions, its role has been emerging in a number of diseases including COPD. ${ }^{5,6}$ Various studies have shown correlation between low serum vitamin $D$ levels and severity of COPD. ${ }^{78}$ Vitamin $\mathrm{D}$ is also useful in maintaining bone, muscle and cardiovascular health which is found to be beneficial in COPD rehabilitation. Supplementation of Vitamin $D$ is found to be beneficial in advanced COPD cases with low serum vitamin D level. Several studies have shown low serum vitamin $D$ levels in patients with COPD. The aim of this study was to compare serum vitamin D level in patients with Global Initiative for Chronic Obstructive Lung Diseases (GOLD) COPD stage II, III and IV with controls and correlate serum vitamin $\mathrm{D}$ level with severity of COPD. 
Table 1. Serum vitamin D level in cases and controls

\begin{tabular}{lccccc}
\hline \multirow{2}{*}{$\begin{array}{c}\text { Study } \\
\text { groups }\end{array}$} & \multicolumn{4}{c}{ Serum vitamin D level $(\mathrm{ng} / \mathrm{ml})$} & \\
\cline { 2 - 5 } & Mean & Max. & Min. & SD & p-value \\
\hline Cases & 15.16 & 40.40 & 8.00 & 7.19 & $<0.0001$ \\
Control & 33.99 & 91.80 & 18.20 & 12.37 & \\
\hline
\end{tabular}

\section{METHODS}

A cross sectional study was conducted from June 2014 to November 2015 at Tribhuvan University Teaching hospital (TUTH). A total of 154 subjects were enrolled for study. Seventy seven cases of COPD with 77 controls for comparison were taken from medical wards and outpatient department (OPD). COPD staging was done as per Global Initiative for Chronic Obstructive Lung Diseases (GOLD) guidelines and stage II, III and IV were labeled as advanced COPD cases on the basis of history, physical examination, chest $X$-ray and pulmonary function test (PFT) of post bronchodilator FEV1/ FVC $<70 \%$ and FEV1 < 80\% of predicted for given age and sex. Controls were taken as subjects without COPD, more than 40 years of age from medical ward and OPD. Subjects with non-specific body ache, persistent lethargy, active cancer, sarcoidosis, asthma, chronic kidney disease, hypocalcaemia and those taking oral steroids, antiepileptic drugs and Vitamin D supplements were excluded from the study. Serum vitamin D level of both cases and controls was obtained. Serum vitamin $\mathrm{D}$ level was measured in TUTH biochemistry laboratory using Chemi Luminescent Immuno Assay (CLIA). Data entry and analysis were done in SPSS version 20. Both descriptive and inferential statistics were performed. In descriptive statistics, frequency, mean and standard deviation were computed while in inferential statistics, independent t-test, one-way ANOVA, chi-square test and Pearson correlation test were performed and $p$-value of $<0.05$ was considered to be statistically significant.

\section{RESULTS}

The mean age of cases with COPD was $65 \pm 12.62$ years (mean $\pm S D$ ), with range from 40 to 95 years. Mean age of control group was $59.6 \pm 9.7$ years (mean \pm SD) with range from 42 to 84 years.

In sex distribution, the study population comprised of $41.6 \%$ male $(n=32)$ and $58.4 \%$ female $(n=45)$ in cases whereas $42.8 \%$ male $(n=33)$ and $57.2 \%$ female $(n=44)$ in control.

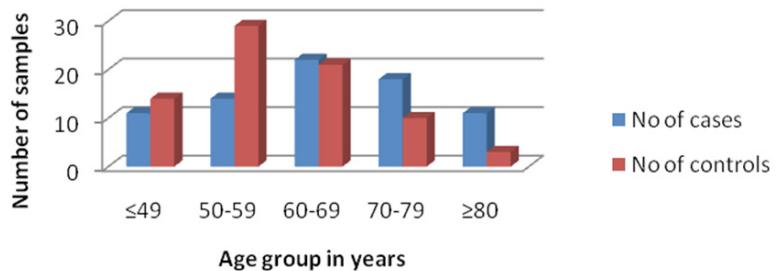

Figure 1. Bar diagram showing age distribution of cases and controls

In COPD cases, the mean serum vitamin $D$ level was $15.16 \pm 7.19 \mathrm{ng} / \mathrm{ml}$ (mean $\pm \mathrm{SD}$ ) with range of $8 \mathrm{ng} / \mathrm{ml}$ to $40.4 \mathrm{ng} / \mathrm{ml}$. In control group, the mean serum vitamin D level was $33.99 \pm 12.37 \mathrm{ng} / \mathrm{ml}($ mean \pm SD) with range of $18.20 \mathrm{ng} / \mathrm{ml}$ to $91.80 \mathrm{ng} / \mathrm{ml}$. The difference in means of serum vitamin $D$ level in cases and controls was found to be statistically significant ( $p<0.0001$ ) (Table 1).

Out of 77 cases, 21 (27.3\%) had severe deficiency, 42 (54.5\%) had deficiency, 10 (13\%) had insufficiency and $4(5.2 \%)$ had sufficiency of Vitamin D whereas out of 77 controls none had severe deficiency, $2(2.6 \%)$ had deficiency, 31 (40.3\%) had insufficiency and $44(57.1 \%)$ had sufficiency of Vitamin D.

Out of total 77 COPD cases, 30\% (n=23) had moderate COPD, 36\% $(n=28)$ had severe COPD and $34 \%(n=26)$ had very Severe COPD. Serum vitamin D level in COPD stages II, III and IV was found as shown in Table 2.

The comparison of serum vitamin $D$ in different stages of COPD showed that serum vitamin $D$ was found to be in decreasing trend with increasing severity of COPD according to GOLD staging. However, the difference in serum Vitamin D level in these groups was not found to statistically significant $(p=0.36)$.

\section{DISCUSSION}

In this study, the mean serum vitamin $D$ level in COPD cases was $15.16 \pm 7.19 \mathrm{ng} / \mathrm{ml}$ (mean \pm SD) with range of $8 \mathrm{ng} / \mathrm{ml}$ to $40.4 \mathrm{ng} / \mathrm{ml}$. In control group, the mean serum vitamin D level was $33.99 \pm 12.37 \mathrm{ng} /$ $\mathrm{ml}$ (mean $\pm \mathrm{SD}$ ) with range of $18.20 \mathrm{ng} / \mathrm{ml}$ to 91.80 $\mathrm{ng} / \mathrm{ml}$. This is comparable with the finding by Nasef Abdel et al9 who showed mean serum vitamin $D$ level $11.80 \pm 2.40 \mathrm{ng} / \mathrm{dl}$ in patients with COPD. In this study $95 \%$ of cases with advanced COPD (stage II, III, IV) had low serum vitamin D levels compared to $43 \%$ in controls ( $p<0.0001$ ). These findings are consistent with findings in other studies comparing

Table 2. Comparison of serum vitamin D level in different stages of COPD cases

\begin{tabular}{|c|c|c|c|c|c|}
\hline \multirow{2}{*}{ GOLD staging of COPD } & \multirow{2}{*}{$\begin{array}{l}\text { Number of cases } \\
\qquad(n=77)\end{array}$} & \multicolumn{3}{|c|}{ Serum vitamin D level (ng/ml) } & \multirow{2}{*}{$p$-value } \\
\hline & & mean $\pm S D$ & Minimum & Maximum & \\
\hline Stage 2 (Moderate) & $23(30 \%)$ & $16.79 \pm 7.96$ & 8.0 & 39.8 & 0.360 \\
\hline Stage 3 (Severe) & $28(36 \%)$ & $15.06 \pm 5.36$ & 8.0 & 26.6 & \\
\hline Stage 4 (Very severe) & $26(34 \%)$ & $13.83 \pm 8.11$ & 8.0 & 40.4 & \\
\hline
\end{tabular}


serum vitamin D level in patients with COPD. A study done by Janssens et al ${ }^{7}$ reported a high prevalence of vitamin D deficiency in patients with COPD from a cohort which included age, sex and smoking-matched with controls. In the same study, they found that in comparison to $31 \%$ of smokers with normal lung function, as many as $60 \%$ and $77 \%$ of patients with GOLD stage III and IV exhibited deficient vitamin D levels with level $<20 \mathrm{ng} / \mathrm{ml}$. A study done by Ali Kocabas et $a^{10}$ showed decreased serum Vitamin $D$ levels in COPD cases with increase in risk of Vitamin $\mathrm{D}$ deficiency by 2.8 times in severe and very severe COPD when mild and moderate COPD were taken as reference. The risk was 4.83 times in very severe COPD when compared to mild COPD. Study done by Mehrnaz Asadi Gharabaghi et al in Iran in $2013^{11}$ and ViDiCO study ${ }^{12}$ showed that patients with COPD had Vitamin $D$ deficiency. The findings of these studies are also consistent with our study.

In this study mean serum vitamin $D$ level was $16.79 \pm 7.96 \mathrm{ng} / \mathrm{ml}$ in moderate COPD, $15.06 \pm 5.36$ $\mathrm{ng} / \mathrm{ml}$ in severe COPD and $13.03 \pm 8.11 \mathrm{ng} / \mathrm{ml}$ in very severe COPD. The comparison of serum vitamin $D$ in different stages of COPD showed that serum vitamin $D$ was found to be in decreasing trend with increasing severity of GOLD COPD staging. However, the difference in serum vitamin D level in these groups was not found to statistically significant $(p=0.36)$. This might be due to the exclusion of mild COPD cases (GOLD stage I). Apart from that, 9 cases in very severe COPD group had serum vitamin D level $<8 \mathrm{ng} / \mathrm{ml}$ which had been taken as $8 \mathrm{ng} / \mathrm{ml}$ during analysis, the real quantitative analysis of which could have given result in favor as seen in study by Ali Kocbas et al. ${ }^{10}$

In this study, the mean serum vitamin D level in control was $33.99 \pm 12.37 \mathrm{ng} / \mathrm{ml}($ mean $\pm S D$ ) with range from $18.2 \mathrm{ng} / \mathrm{ml}$ to $91.8 \mathrm{ng} / \mathrm{ml}$. A study done by Shrestha $\mathrm{S}$ et $\mathrm{al}^{13}$ at Nepal Medical College which included 46 cases in elder health home care, Nepal showed 41 out of 46 patients had low vitamin D levels with 36 having deficiency. In the same study, subjects with age more than 50 years had low Vitamin D levels compared to those less than 50 years of age. In this study, there was no significant difference in serum vitamin $D$ level with increasing age as seen in study done by Vieth et $\mathrm{al}^{14}$ which showed that there was no difference in serum vitamin $D$ level with increasing age though requirement to maintain the serum vitamin $\mathrm{D}$ level increased with age. This study shows that patients with advanced COPD (GOLD stage II, III, IV) are deficient in serum vitamin D compared to healthy controls which was found to be in decreasing trend with increasing severity of COPD.

\section{CONCLUSION}

Patients with advanced COPD (GOLD stage II, III and IV) have low serum vitamin D levels compared to normal population and serum vitamin D level decreases with increasing severity of COPD. Hence, vitamin $\mathrm{D}$ supplements could be considered in patients with COPD for better rehabilitation, improving quality of life and reducing morbidity and mortality. However, baseline serum vitamin D level hasn't been established well in Nepalese population. Hence, further studies are needed to establish baseline vitamin D level in healthy Nepalese population.

\section{CONFLICT OF INTEREST}

None declared.

\section{REFERENCES}

1. Suzanne Hurd. The impact of COPD on drug health worldwide, epidemiology and incidence. Chest 2000; 117:13-43

2. World Health Organization. World health report 2002: reducing risks, promoting healthy life.

3. S. Christakos,P. Dhawan,Y. Liu,X. Peng,A. Porta New insights into the mechanisms of vitamin D action $\mathrm{J}$ Cell Biochem, 88 (2003), pp. 695-705

4. F. Baeke,T. Takiishi,H. Korf,C. Gysemans,C. Mathieu Vitamin D: modulator of the immune system Curr Opin Pharmacol, 10 (2010), pp. 482-496

5. C. Herr,T. Greulich,R.A. Koczulla,S. Meyer,T. Zakharkina,M. Branscheidt The role of vitamin $D$ in pulmonary disease: COPD, asthma, infection, and cancer Respir Res, 12 (2011), pp. 31

6. James D, Finklea, Ruth E. Grossmann, and Vin Tangpricha, Vitamin D and Chronic Lung Disease: A Review of Molecular Mechanisms and Clinical Studies,

7. Janssens W, Bouillon R, Claes B, Carremans C, Lehouck A, Buysschaert I,Coolen et al. Vitamin D deficiency is highly prevalent in COPD and correlates with variants in the vitamin D-binding gene. Thorax.2010; 65:215-20.

8. Mehrnaz Asadi Gharabaghi, Mehrnoush Asadi Ghrabaghi, Mohsen Arabi, Mohammad Reza Zahedpour Anaraki and Gholamreza Derakhshan Deilami, Obstructive Pulmonary Disease. J Gerontol Geriat Res 2:127

9. Nasef Abdel Salam A. Rezka, Nasser Yehia A. Alyb, Asem Abdel Hamid Hewidya, Egyptian Journal of Chest Diseases and Tuberculosis, doi:10.1016/j. ejcdt.2015.01.002

10. Ali Kocabas, Mujde Cigerli Ocak, Sedat Kulesi, Gulash Seydaoglu: ATS journals, 2013

11. Mehrnaz Asadi Gharabaghi, Mehrnoush Asadi Ghrabaghi, Mohsen Arabi, Mohammad Reza Zahedpour Anaraki and Gholamreza Derakhshan Deilami, Obstructive Pulmonary Disease. J Gerontol Geriat Res 2:127

12. Adrian R Martineau, Wai Yee James, Richard L Hooper, Neil C Barnes, David A Jolliffee et al. Vitamin D3 supplementation in patients with chronic obstructive pulmonary disease (ViDiCO): A multicentre, doubleblind, randomised controlled trial The Lance

13. S Shrestha, L Shrestha, DK Jha,Vitamin D status among individuals attended in Health Home Care Centre, Lalitpur, Nepal Nepal Med Coll J 2012; 14(2): 84-87

14. Vieth Reinhold, Yasmin Ladak, and Paul G. Walfish. "Agerelated changes in the 25-hydroxyvitamin $D$ versus parathyroid hormone relationship suggest a different reason why older adults require more vitamin D." The Journal of Clinical Endocrinology \& Metabolism 88.1 (2003): 185-191 